\title{
Lantana camara: A Comprehensive Review on Phytochemistry, Ethnopharmacology and Essential Oil Composition
}

\author{
Muzammil Shah ${ }^{1, *(\mathbb{D})}$, Hesham F.Alharby ${ }^{1}$ (i) , Khalid Rehman Hakeem ${ }^{1(\mathbb{D})}$ \\ 1 Department of Biological Sciences, Faculty of Science, King Abdulaziz University, Jeddah 21589, Saudi Arabia \\ * Correspondence: muzammilshah100@ outlook.com;
}

Scopus Author ID 57204315164 Received: 22.05.2020; Revised: 13.06.2020; Accepted: 14.06.2020; Published: 15.06.2020

\begin{abstract}
In the present era, researchers are focusing on medicinal plant research throughout the world as medicinal plants are an important and cheap source of drugs and have a long history. Most of the remedies in the traditional system were taken from plants due to lack of technology, and using plants as medicines were proven to be useful. Lantana camara L. (Verbenaceae) is an aromatic plant as well as a rich source of medicinal compounds. From decades the plant is used to treat many diseases i.e., malaria, fever, cold and cough etc. Several essential phytochemicals have been isolated from L.camara L., including triterpenoids, flavonoids, alkaloids, saponins, steroids, and tannins. Moreover, it is also known as an essential oil-producing plant, and the essential oil is available in the market known as Lantana oils. Thus due to the above mentioned economic as well as medicinal properties of L.camara $\mathrm{L}$; there is a need of a comprehensive report on the ethnobotanical, phytochemical, pharmacological and toxicological aspects of $L$. camara $\mathrm{L}$. This review will be useful for researchers working in the field of genomics, metabolomics and molecular studies of medicinal plants.
\end{abstract}

Keywords: Lantana camara; medicinal plants; Verbenaceae; pharmacology; toxicology.

(C) 2020 by the authors. This article is an open-access article distributed under the terms and conditions of the Creative Commons Attribution (CC BY) license (https://creativecommons.org/licenses/by/4.0/).

\section{Introduction}

The genus Lantana camara L. is an important medicinal, ornamental, as well as essential oil-producing plant from family Verbenaceae and termed by Linnaeus in 1753. It is mainly composed of seven species, with six reported from America and one from Ethiopia [1]. It is innate to South America, but some of the taxes can be found in almost 50 countries of the world, and in some countries, it can be cultivated as well [2]. It is also known as red sage and is used as a popular ornamental plant in gardens [3]. L. camara grows in tropical, subtropical, and temperate regions at a high altitude up to $2000 \mathrm{~m}$ [4]. The plant has a woody stem with several different colors of flowers i.e., red, white, pink as well as the plant contain spines or prickles [1]. The genus consists of 650 cultivars, but the majority is related to the L.camara complex. It is also considered as a noxious weed globally [5]. Moreover, it is stated that the ash of L.camara contains manganese and potassium, which are useful for coconut trees [2]. Few reports consider it as a poisonous plant for humans as well as animals [6,7]. Traditionally, L. camara has been used as a medication to treat various diseases such as cancer, tumors, tetanus, cuts, eczema, measles, chickenpox, fevers, rheumatism, and asthma [8,9]. L.camara possesses therapeutic potential because of various bioactive components, including steroids, 
triterpenoids, oligosaccharides, iridoid glycosides, naphthoquinones, and phenylpropanoid glycosides [10,11].

Different important phytochemicals have been isolated from L.camara including ursolic acid, oleanolic acid, linaroside, lantanoside, verbascoside, camarinic acid, phytol and umuhengerin, and their biological activities have been well studied [10,12,13]. Additionally, the plant is also known as one of the best as well as easily obtainable materials for the isolation of EOs branded as Lantana oils [14]. These important EOs obtained from L.camara from different localities have been reported [12,15], and there important biological activities, including anti-inflammatory [16], antioxidants [17], as well as antibacterial [18] have been reported. However, up to date, almost 41 sequences, including (rps3, atpB, ccsA, rpoC1, rpoC2, FT, GLO1,rpl32 and rbcL) have been deposited in the NCBI Genbank database [19] and recently the genome of L.camara is also reported [20]. Looking at the medicinal and economic importance of $L$. camara there is a need for a comprehensive review for gathering all the information about its pharmacology, toxicology, and phytochemistry. This review will serve as a baseline for further molecular studies of L.camara.

\section{Scientific Classification and Plant Description}

Family: Verbenaceae

Scientific name: Lantana camara

Kingdom: Plantae

Order: Lamiales

Lantana camara is an erect vigorous shrub that usually grows up to a height of 4 meters. The leaf is ovate or ovate-oblong shaped with a size 2-10 cm (length) and 2-6 cm (width). Leaves are green and tough with fine hairs and have a pungent odor, and it have the ability to climb up to 15 meters with the help of support. It can easily grow in favorable conditions, and flowers usually appear in the month of March and August. The color of the fruit is green and drupaceous with two nutlets. Mature plants produce up to 2000 seeds annually. The roots of L.camara are very strong, having a main taproot with many small side roots [21].

Table 1. A list of major constituents of L. camara essential oils reported from different countries of the world.

\begin{tabular}{|c|c|c|c|}
\hline Sr\# & Countries & Compounds (\%) & References \\
\hline 1 & Saudi Arabia & $\begin{array}{l}\text { spathulenol, caryophyllene oxide, 1-octen-3-ol, 1-hexanol, } \boldsymbol{\beta} \text { - } \\
\text { caryophyllene, spathulenol, c-cadinene and trans-b-farnesene, cis-3- } \\
\text { hexen-1-ol, }\end{array}$ & {$[15]$} \\
\hline 2 & Congo & $\beta$-Caryophyllene, $\alpha$-humulene, bicyclogermacrene. & [27] \\
\hline 3 & Iran & $\begin{array}{l}\text { } \beta \text {-Caryophyllene, sabinene, bicyclogermacrene, } \alpha \text {-humulene, } 1,8 \\
\text { cineole. }\end{array}$ & {$[28]$} \\
\hline 4 & Cameroon & ar-Curcumene, $\boldsymbol{\beta}$-caryophyllene, caryophyllene epoxide II. & [29] \\
\hline 5 & Algeria & $\boldsymbol{\beta}$-Caryophyllene, caryophyllene oxide, $\beta$-elemene. & [30] \\
\hline 6 & Madagaskar & $\boldsymbol{\beta}$-Caryophyllene, davanone, sabinene, linalool, $\alpha$-humulene. & [14] \\
\hline 7 & Nigeria & $\alpha$-humulene. 1,8-cineole, $\boldsymbol{\beta}$-caryophyllene, Sabinene, & [31] \\
\hline 8 & South China & $\beta$-caryophyllene, $\alpha$-humulene, germacrene-B. Germacrene-D, & [32] \\
\hline 9 & Egypt & $\begin{array}{l}\text { germacrene-D, } \boldsymbol{\beta} \text {-Caryophyllene, bicyclogermacrene, Farnesol, } \\
\text { spathulenol, } \alpha \text {-humulene. }\end{array}$ & [33] \\
\hline 10 & Brazil & $\begin{array}{l}\boldsymbol{\beta} \text {-Caryophyllene, germacrene-D, bicyclogermacrene, germacrene-D-4- } \\
\text { ol. }\end{array}$ & {$[34,35]$} \\
\hline 11 & India & $\begin{array}{l}\text { Germacrene-D, } \beta \text {-elemene, } \gamma \text {-elemene, } \boldsymbol{\beta} \text {-caryophyllene, } \alpha \text {-copaene, } \alpha \\
\text {-cadinene. }\end{array}$ & {$[36,37]$} \\
\hline 12 & Cuba & E-nerolidol, d-cadinene, $\alpha$-humulene, $\boldsymbol{\beta}$-caryophyllene. & [38] \\
\hline
\end{tabular}




\section{Phytochemistry}

L.camara is a medicinal plant, and due to this property, all parts of the plant were studied for chemical compounds. The leaf extracts were found to have the majority of chemical constituents including Triterpenoids, alkaloids, flavonoids, tannins, saponins, glycosides [15,17,22-24]. In spite of leaves, phytochemical studies of L.camara stem and fruit were also performed [22]. They reported tannins, saponins, flavonoids, and terpenoids from stem and fruit. The following compounds were reported by GC/MS analysis of the fruit in an n-Hexane fraction [22].

It was described that the root of the plant contains important bioactive compound 'Oleanolic acid', and its isolation procedure has been patented [25,26]. L.camara is also known as a rich source of essential oils and is available in the market named as Lantana oils [14]. More details of the essential oils chemical constituents reported from different countries are given (Table 1).

If we make a comparative analysis of Saudi Arabian essential oil composition with the essential oil reported from other countries, it is attention-grabbing to discuss that the composition of essential oils reported from Saudi Arabia is different compared to other countries. As mentioned in (Table 1) cis-3-hexen-1-ol and 1-hexanol are key constituents of L.camara essential oils, which are reported first time from Saudi Arabia and have not been detected by earlier studies [15]. Furthermore, $\beta$-caryophyllene (natural bicyclic sesquiterpene) is a vital compound present in all the essential oils composition reported so far. Therefore, it is suggested that $\beta$-caryophyllene should be taken for further investigation and can be tested as a potent marker for L.camara essential oils.

\section{Ethnopharmacology}

Lantana camara $\mathrm{L}$. is a medicinal plant have used worldwide to cure various diseases [9]. It's leaves can be boiled and used as a tea, and its decoction is used for the treatment of cough, tetanus, malaria, and the lotion made from the leaves can be used to treat wounds [24]. In Ghana, the infusion prepared from the whole plant is used for treating bronchitis, and roots powder form mixed with milk is used for curing stomach pain [39]. A previous report shows that lancamarone, an important steroid isolated from the leaves of L.camara possess cardiotonic potentials [40]. Traditionally, its leaves can be used as a tonic for abdominal pains as well as it can be used as an insecticide [41]. In some countries of Asia, the leaves of the plant have been used to cure cuts, ulcers, and rheumatisms [13].

\section{Pharmacological Properties}

L.camara being a medicinal plant, has several pharmacological properties mentioned below.

\subsection{Antifungal and antibacterial activities.}

L.camara as a medicinal plant, possesses vital antifungal potential. Its antifungal potential was screened against Alternaria sp. a pathogenic fungus causing diseases, especially in vegetables. The food poison plate technique was used to perform the antifungal activity with three different concentrations of extract i.e., $10 \mathrm{mg} / \mathrm{ml}, 15 \mathrm{mg} / \mathrm{ml}$, and $20 \mathrm{mg} / \mathrm{ml}$. It was noted that at $20 \mathrm{mg} / \mathrm{ml}$, the plant displayed noteworthy antifungal activity against Alternaria sp. [42]. 
An ethanolic and hot water extract was used against white and brown rot fungi known as wooddestroying fungi. Significant antifungal activity was seen in both extracts; however, low concentration $(0.01 \%)$ ethanolic extract was more significant [43].

L.camara possesses antibacterial potential as a different part i.e., leaves and flowers have shown strong antibacterial activity. It was reported that leaf and flower tissue samples of L.camara in three different kinds of the solvent extract showed noteworthy activity against different bacteria i.e., P. aeruginosa, Bacillus subtilis, and E. coli ; however low antibacterial activity was reported against $S$. aureus [4]. In another study, an ethanolic extract prepared from L. camara leaf and root tissues were testified, and the microdilution method was used for in vitro antibacterial activity. The results showed significant antibacterial activities in response to S. aureus, $P$. vulgaris, P.aeruginosa, V.cholareae, E. coli [44].

Previous studies reported that different organs of $L$. camara were ground into powder, and methanol was used to prepare the extracts and were subjected for antimicrobial activities against ten bacteria and five fungi by taking and advantage of disk diffusion broth microdilution methodologies. The activities showed significant results against Bacillus cereus and Salmonella typhi [45].

\subsection{Antiulcerogenic and antihyperglycemic activities.}

In order to discover the antiulcerogenic potential of L.camara a methanolic extract was prepared and its evaluation was done in aspirin-induced gastric ulcerogenesis in pyloric ligated rats, ethanol-induced gastric ulcer, and cysteamine induced duodenal ulcer models. Two different oral dosages of the extract were given with $250 \mathrm{mg} / \mathrm{kg}$ and $500 \mathrm{mg} / \mathrm{kg}$. The results of L. camara extract showed significant $(\mathrm{P}<0.01)$ reduction in ulcer index, total acidity as well as significant $(\mathrm{P}<0.01)$ increase in the gastric $\mathrm{pH}$ of aspirin+pylorus-ligation induced ulcerogenesis and ethanol-induced gastric ulcer models. Thus it was concluded that leaves of L.camara have the potential healing of gastric ulcers and can prevent intestinal ulcers in rats [13].

In another study, a methanolic extract from leaf tissues was prepared, and its effect was studied on aspirin, ethanol, and cold restraint stress-induced gastric lesions in rat models. The results revealed antiulcerogenic activity in a dose-dependent manner and reduce the volume of gastric juice, total acidity, free acidity but showed a significant $(\mathrm{P}<0.001)$ enhancement in $\mathrm{pH}$ levels in aspirin-induced gastric ulcer. When a pre-treatment was given with two dosages (200 and $400 \mathrm{mg} / \mathrm{kg}$ ) an ulcer protective effect was seen with a protection percentage of $(63.31 \%$, $71.02 \%)$ in aspirin-induced, $(85.79 \%, 93.09 \%)$ in ethanol-induced and $(46.86 \%, 63.90 \%)$ protection in cold restraint stress-induced ulcer models. It was shown that the extract possesses in vivo antioxidant potentials as an increase was noticed in superoxide dismutase (SOD), catalase, reduces glutathione (GR) activities in the treated group [46].

The antihyperglycemic activity was also performed using methanolic extract prepared from $L$. camara leaf tissues and subjected to alloxan-induced diabetic rats. The extract was orally administered $(400 \mathrm{mg} / \mathrm{kg})$, and the results stated a reduction in glucose level to (121.94 $\mathrm{mg} / \mathrm{dl}$ ) in the blood in alloxan-induced diabetic rats [47]. Additionally, the hypoglycemic activity of methanolic extracts of the fruit was tested in streptozotocin-induced diabetic rats. As a result $\mathrm{s}$ a dose-dependent reduction was seen in the glucose level of serum as well as development in body weight, HbA1c profile and liver cells regeneration in streptozotocin induced diabetic rats [48]. 


\subsection{Nematicidal and insecticidal activities.}

To investigate the nematicidal potential of $L$. camara various concentrations of leaf extract were considered under in-vitro conditions against second-stage juveniles (J2) of Meloidogyne incognita. When the standard condition ' $\mathrm{S}$ ' (an extract made of leaf tissues) was given and checked after 12 and $48 \mathrm{~h}$, the result noted was highly nematostatic, and nematodes were found paralyzed, however, at the same concentration, $96 \%$ of juveniles were seen to be dead. Nonetheless, in S2 dilution at 48 hours, the mortality rate of juveniles was found $75 \%$ [49].

It was shown that lantanilic acids, camaric acid, as well as oleanolic acid possess nematicidal activities. Further investigation and isolation were done by bio-assay guided fractionation method using extract prepared with methanol from the aerial parts of $L$. camara $\mathrm{L}$. The result showed $98 \%, 95 \%$ and $70 \%$ mortality rate against Meloidogyne incognita (root-knot nematode) at $0.5 \%$ concentration. However, furadan an important insecticide displayed $100 \%$ mortality $0.5 \%$ concentration [50].

L.camara exhibits strong activities against different insects. To identify the potential of insecticidal activity an extract was prepared from leaf tissues, and it was noticed that the extract possess fumigant and have shown significant toxicity against $S$. oryzae, C. chinesis and $T$. castaneum. The results of the fumigant assay indicated that the $\mathrm{LC}_{50}$ for $T$. castaneum was $(178.7 \mu \mathrm{l} / \mathrm{L}), C$. chinensis $(130.3 \mu \mathrm{l} / \mathrm{L})$, as well as $S$. oryzae was $(128 \mu \mathrm{l} / \mathrm{L})$. However, the values of $\mathrm{LD}_{50}$ in contact toxicity for $S$. oryzae were (0.158), C. chinensis $(0.140)$, and $T$. castaneum $\left(0.208 \mathrm{mg} / \mathrm{cm}^{2}\right)$. The results of grain treatment indicated that 7 days exposure and $500 \mathrm{mg} / \mathrm{L}$ concentrations are required for obtaining $90-100 \%$ extinction of the population in these insects. Furthermore, by using probit analysis, it was suggested that $C$. chinensis were more susceptible than S. oryzae and T. castaneum [51].

In the additional study, an investigation was done on L. camara in order to find their insecticidal, antifeedant, and antiovipositional activities against Callosobruchus chinensis. The results showed that petroleum ether and methanolic extracts of the plant possess a $10-43 \%$ mortality rate at $1-5 \%$ concentrations with a reduction in fecundity rate at higher dosages. The antiovipositional values for petroleum ether extract were $30 \mathrm{mg} / 100 \mathrm{~g}$ and $40 \mathrm{mg} / 100 \mathrm{~g}$ of seed for methanolic extract [52].

\subsection{Antipyretic and antihelmentic activities.}

The antipyretic activity of L.camara was determined by using ethanolic and ethyl acetate extracts. The results showed a decrease in body temperature from the $1.5^{\text {th }}$ hour. However, the antipyretic activity for both the extracts was significant $(\mathrm{P}<0.01)$ between the 2nd and 3rd hour as compared with the negative control [53].

Helminths, also known as parasitic worms, are pathogens of great importance worldwide. Nowadays, billions of people, especially in the least developed countries, are infected with soil-transmitted helminths. Helminths infection is also a severe problem in livestock production globally and has caused significant loss to the economy as well as threatened food security. In order to find a solution for such serious problems, L. camara L. was selected for its anthelmintic activity against Pheretima posthuma. An ethanolic extract was made using the stem of L.camara L. and subjected for investigation of anthelmintic potential. The analysis showed a significant result at $500 \mathrm{mg} / \mathrm{ml}$ dosage when compared to standard drug albendazole at $20 \mathrm{mg} / \mathrm{ml}$ concentration [60]. 


\subsection{Larvicidal and wound healing activities.}

Mosquitoes are a group of insects that affect human beings more than any other organism. Although the loss of blood by mosquitos bite from human beings is trivial, but several contagious diseases i.e., fever, malaria, dengue, caused by these mosquitoes, are of great importance in terms of public health as a step forward to find cure for such diseases, researchers have done a lot of studies by using various parts of L.camara extracts.

Mosquito larvicidal activity of extracts prepared using leaf and flower tissues of $L$. camara L. in methanol and ethanol have been thoroughly studied. As a step forward, the larvae of $A$. aegypti and $C$. quinquefasciatus (mosquito species) were used for (24h) in a dosedependent manner. The outcomes showed a maximum mortality rate in A. aegypti with 1.0 $\mathrm{mg} / \mathrm{ml}$ concentration of extracts of L.camara when exposed for 24 hours. However, in C. quinquefasciatus, the death rate was high with an increase in concentration to $3.0 \mathrm{mg} / \mathrm{ml}$ [55].

In the additional study, an extract from L.camara leaf tissues was prepared to determine its efficiency against mosquito larvae. The effects showed that L.camara is the best larvicide as the larvae required $80 \mathrm{mg} / 100 \mathrm{ml}$ concentration of the aqueous extract for 6 hours for getting $100 \%$ mortality rate [56]. Additionally, in another study, extracts from various parts of the plant were made and screened for activity in the brine shrimp lethality test (BST). The important compounds oleanonic acid, lantadene A, and oleanolic acid showed toxicity towards brine shrimp larvae. However, these compounds were not fatal to Spodoptera littoralis Biosduval (Lepidoptera: Noctuidae), Clavigralla tomentosicollis Stal. (Hemiptera: Coreidae) and Aphis craccivora Koch (Homoptera: Aphididae), when tested at 5000 $\mathrm{\mu g} / \mathrm{ml}$ and compound Lantadene A, inhibited the fecundity of $C$. tomentosicollis at this concentration [57].

\section{Conclusions}

There is a high increase in demand for herbal drugs nowadays. Plants are famous for possessing many chemical moieties with a lot of pharmacological properties. Many powerful and efficient drugs have been isolated from medicinal plants for treating dreadful diseases. Thus it is very clear that the studies of medicinal plants are very significant for the benefits of human beings in terms of manufacturing herbal drugs. Lantana camara is among those vital medicinal plants which have been used as folk medicine globally. Several phytochemical reports showed that the plant is rich in important chemical compounds as well as essential oils. Steroids, coumarin, monoterpenoids, flavonoids, diterpenes, including many other chemical compounds have been reported from L camara. Maximum numbers of the pharmacological investigations carried out on L camara are just preliminary tests on some animal models. These studies are not sufficient in order to develop pharmaceutical products. However, intensive preclinical and clinical research studies are needed for the evaluation of the efficacy and toxicity of these products. Additionally, more research is required for the investigation of the unexplored potential of this important medicinal plant.

\section{Funding}

This research received no external funding. 


\section{Acknowledgments}

The first author is thankful to King Abdulaziz University, Jeddah, Saudi Arabia, for providing Ph.D. Scholarship.

\section{Conflicts of Interest}

The authors declare no conflict of interest.

\section{References}

1. Joy, J.M.; Vamsi, S.; Satish, C.; Nagaveni, K. Lantana camara Linn: a review. International Journal of Phytotherapy 2012, 2, 66-73.

2. Ghisalberti, E.L. Lantana camara L.(verbenaceae). Fitoterapia 2000, 71, 467-486, https://doi.org/10.1016/S0367-326X(00)00202-1.

3. Munir, A.A. A revision taxonomic of Lantana camara L. and L. montevidensis Briq.(Verbenaceae) in Australia. J Adelaide Bot Gard 1996, 17, 1-27.

4. Ganjewala, D.; Sam, S.; Khan, K.H. Biochemical compositions and antibacterial activities of Lantana camara plants with yellow, lavender, red and white flowers. EurAsian Journal of BioSciences 2009, 3, 6977.

5. Sharma, O.P.; Makkar, H.P.S.; Dawra, R.K. A review of the noxious plant Lantana camara. Toxicon 1988, 26, 975-987, https://doi.org/10.1016/0041-0101(88)90196-1.

6. Morton, J.F. Pito (Erythrina berteroana) and chipilin (Crotalaria longirostrata),(Fabaceae) two soporific vegetables of Central America. Economic botany 1994, 48, 130-138, https://doi.org/10.1007/BF02908199.

7. Ross, I.A. Medicinal plants of the world: chemical constituents, traditional and modern medicinal uses. Ross, I.A. 2000.

8. Day, M.D.; Wiley, C.J.; Playford, J.; Zalucki, M.P. Lantana: current management status and future prospects; 2003;

9. Ghisalberti, E.L. Lantana camara L.(verbenaceae). Fitoterapia 2000, 71, 467-486, https://doi.org/10.1016/S0367-326X(00)00202-1.

10. Begum, S.; Ayub, A.; Qamar Zehra, S.; Shaheen Siddiqui, B.; Iqbal Choudhary, M. Leishmanicidal triterpenes from Lantana camara. Chemistry \& biodiversity 2014, 11, 709-718, https://doi.org/10.1002/cbdv.201300151.

11. Sousa, E.O.; Almeida, T.S.; Menezes, I.R.; Rodrigues, F.F.; Campos, A.R.; Lima, S.G.; da Costa, J.G. Chemical composition of essential oil of Lantana camara L.(Verbenaceae) and synergistic effect of the aminoglycosides gentamicin and amikacin. Records of Natural Products 2012, 6.

12. de Sena Filho, J.G.; Rabbani, A.R.C.; dos Santos Silva, T.R.; da Silva, A.V.C.; Souza, I.A.; Santos, M.J.B.A.; de Jesus, J.R.; de Lima Nogueira, P.C.; Duringer, J.M. Chemical and molecular characterization of fifteen species from the Lantana (Verbenaceae) genus. Biochemical systematics and ecology 2012, 45, 130-137, https://doi.org/10.1016/j.bse.2012.07.024.

13. Sathish, R.; Vyawahare, B.; Natarajan, K. Antiulcerogenic activity of Lantana camara leaves on gastric and duodenal ulcers in experimental rats. Journal of ethnopharmacology 2011, 134, 195-197, https://doi.org/10.1016/j.jep.2010.11.049.

14. Randrianalijaona, J.A.; Ramanoelina, P.A.; Rasoarahona, J.R.; Gaydou, E.M. Seasonal and chemotype influences on the chemical composition of Lantana camara L.: Essential oils from Madagascar. Analytica Chimica Acta 2005, 545, 46-52, https://doi.org/10.1016/j.aca.2005.04.028.

15. Khan, M.; Mahmood, A.; Alkhathlan, H.Z. Characterization of leaves and flowers volatile constituents of Lantana camara growing in central region of Saudi Arabia. Arabian Journal of Chemistry 2016, 9, 764-774, https://doi.org/10.1016/j.arabjc.2015.11.005.

16. Benites, J.; Moiteiro, C.; Miguel, G.; Rojo, L.; Lopez, J.; Venancio, F.; Ramalho, L.; Feio, S.; Dandlen, S.; Casanova, H. Composition and biological activity of the essential oil of Peruvian Lantana camara. Journal of the Chilean Chemical Society 2009, 54, 379-384, http://dx.doi.org/10.4067/S071797072009000400012.

17. Sousa, E.O.; Rocha, J.B.; Barros, L.M.; Barros, A.R.; Costa, J.G. Phytochemical characterization and in vitro antioxidant properties of Lantana camara L. and Lantana montevidensis Briq. Industrial crops and products 2013, 43, 517-522, https://doi.org/10.1016/j.indcrop.2012.07.058.

18. Tesch, N.R.; Mora, F.; Rojas, L.; Díaz, T.; Velasco, J.; Yánez, C.; Rios, N.; Carmona, J.; Pasquale, S. Chemical composition and antibacterial activity of the essential oil of Lantana camara var. moritziana. Natural product communications 2011, 6, 1031-4.

19. Goswami-Giri, A.S.; Oza, R. Bioinformatics Overview of lantana camara, an Environmental Weed. Research Jornal of Pharmaceutical Biology and Chemical Sciences 2014, 5, 1712. 
20. Yaradua, S.S.; Shah, M. The complete chloroplast genome of Lantana camara L.(Verbenaceae). Mitochondrial DNA Part B 2020, 5, 918-919, https://doi.org/10.1080/23802359.2020.1719920.

21. Sankaran, K.V. Asia-Pacific Forest Invasive Species Network. The fact sheet is supported by the Food and Agriculture, Organization of the United Nations (FAO) and USDA Forest Service 2007.

22. Bashir, S.; Jabeen, K.; Iqbal, S.; Javed, S.; Naeem, A. Lantana camara: Phytochemical Analysis and Antifungal Prospective. Planta Daninha 2019, 37, https://doi.org/10.1590/s0100-83582019370100137.

23. Bhuvaneswari, E.; Giri, R.S. Physicochemical and phytochemical screening in Lantana camara leaves. Journal of Pharmacognosy and Phytochemistry 2018, 7, 1962-1966.

24. Verma, R.K.; Verma, S.K. Phytochemical and termiticidal study of Lantana camara var. aculeata leaves. Fitoterapia 2006, 77, 466-468, https://doi.org/10.1016/j.fitote.2006.05.014.

25. Banik, R.M.; Pandey, D.K. Optimizing conditions for oleanolic acid extraction from Lantana camara roots using response surface methodology. Industrial crops and products 2008, 27, 241-248, https://doi.org/10.1016/j.indcrop.2007.09.004.

26. Verma, S.C.; Jain, C.L.; Nigam, S.; Padhi, M.M. Rapid extraction, isolation, and quantification of oleanolic acid from Lantana camara L. Roots using microwave and HPLC-PDA techniques. Acta Chromatographica 2013, 25, 181-199, https://doi.org/10.1556/achrom.25.2013.1.12.

27. Ouamba, J.M.; Ouabonzi, A.; Ekouya, A.; Bessière, J.-M.; Menut, C.; Abena, A.A.; Banzouzi, J.T. Volatile constituents of the essential oil leaf of Lantana salvifolia Jacq.(Verbenaceae). Flavour and fragrance journal 2006, 21, 158-161.

28. Sefidkon, F. Essential oil of Lantana camara L. occurring in Iran. Flavour and fragrance Journal 2002, 17, 78-80, https://doi.org/10.1002/ffj.1048.

29. Ngassoum, M.B.; Yonkeu, S.; Jirovetz, L.; Buchbauer, G.; Schmaus, G.; Hammerschmidt, F.J. Chemical composition of essential oils of Lantana camara leaves and flowers from Cameroon and Madagascar. Flavour and fragrance journal 1999, 14, 245-250, https://doi.org/10.1002/(SICI)10991026(199907/08)14:4<245::AID-FFJ819>3.0.CO;2-X.

30. Zoubiri, S.; Baaliouamer, A. GC and GC/MS analyses of the Algerian Lantana camara leaf essential oil: Effect against Sitophilus granarius adults. Journal of Saudi Chemical Society 2012, 16, 291-297, https://doi.org/10.1016/j.jscs.2011.01.013.

31. Kasali, A.A.; Ekundayo, O.; Paul, C.; Koenig, W.A.; Eshilokun, A.O.; Yadua, P. Essential oil of Lantana camara L. var. aculeata from Nigeria. Journal of essential oil Research 2004, 16, 582-584, https://doi.org/10.1080/10412905.2004.9698803.

32. Sundufu, A.J.; Shoushan, H. Chemical composition of the essential oils of Lantana camara L. occurring in south China. Flavour and fragrance journal 2004, 19, 229-232, https://doi.org/10.1002/ffj.1292.

33. Elansary, H.O.; Salem, M.Z.; Ashmawy, N.A.; Yacout, M.M. Chemical composition, antibacterial and antioxidant activities of leaves essential oils from Syzygium cumini L., Cupressus sempervirens L. and Lantana camara L. from Egypt. Journal of Agricultural science 2012, 4, https://doi.org/10.5539/jas.v4n10p144.

34. de Oliveira, J.C.; Neves, I.A.; da Camara, C.A.; Schwartz, M.O. Essential oil composition of two Lantana species from mountain forests of Pernambuco (northeast of Brazil). Journal of Essential Oil Research 2008, 20, 530-532, https://doi.org/10.1080/10412905.2008.9700080.

35. Passos, J.L.; Barbosa, L.C.A.; Demuner, A.J.; Alvarenga, E.S.; Silva, C.M. da; Barreto, R.W. Chemical characterization of volatile compounds of Lantana camara L. and L. radula Sw. and their antifungal activity. Molecules 2012, 17, 11447-11455, https://doi.org/10.3390/molecules171011447.

36. Khan, M.; Srivastava, S.K.; Jain, N.; Syamasundar, K.V.; Yadav, A.K. Chemical composition of fruit and stem essential oils of Lantana camara from northern India. Flavour and fragrance journal 2003, 18, 376379, https://doi.org/10.1002/ffj.1197.

37. Misra, L.; Saikia, A.K. Chemotypic variation in Indian Lantana camara essential oil. Journal of essential oil research 2011, 23, 1-5, https://doi.org/10.1080/10412905.2011.9700449.

38. Pino, J.A.; Marbot, R.; Rosado, A.; Romeu, C.; Mart, M.P. Chemical composition of the essential oil of Lantana camara L. from Cuba. Journal of Essential Oil Research 2004, 16, 216-218, https://doi.org/10.1080/10412905.2004.9698701.

39. Ghisalberti, U.E.L.; Irvine, F.R. Woody plants of Ghana. London: Oxford University Press, 1961;

40. Hussain, H.; Hussain, J.; Al-Harrasi, A.; Shinwari, Z.K. Chemistry of some species genus Lantana. Pakistan journal of botany 2011, 43, 51-62.

41. Yadav, S.B.; Tripathi, V. A new triterpenoid from Lantana camara. Fitoterapia 2003, 74, 320-321, https://doi.org/10.1016/S0367-326X(03)00034-0.

42. Srivastava, D.; Singh, P. Antifungal potential of two common weeds against plant pathogenic fungiAlternaria sps. Asian J. exp. biol. sci 2011, 2, 525-528.

43. Tripathi, S.; Rawat, K.; Dhyani, S.; Pant, H. Potential of Lantana camara Linn. weed against wood destroying fungi. Indian Forester 2009, 135.

44. Barreto, F.S.; Sousa, E.O.; Rodrigues, F.F.G.; Costa, J.G.M.; Campos, A.R. Antibacterial activity of Lantana camara Linn Lantana montevidensis Brig extracts from Cariri-Ceara, Brazil. Journal of Young Pharmacists 2010, 2, 42-44, https://doi.org/10.4103/0975-1483.62211. 
45. Badakhshan, M.P.; Sasidharan, S.; Rameshwar, N.J.; Ramanathan, S. A comparative study: antimicrobial activity of methanol extracts of Lantana camara various parts. Pharmacognosy Research 2009, 1, 348.

46. Thamotharan, G.; Sekar, G.; Ganesh, T.; Sen, S.; Chakraborty, R.; Kumar, S.N. Antiulcerogenic effects of Lantana camara Linn. leaves On in vivo test models in rats. Asian journal of pharmaceutical and clinical research 2010, 3, 57-60.

47. Ganesh, T.; Sen, S.; Thilagam, E.; Thamotharan, G.; Loganathan, T.; Chakraborty, R. Pharmacognostic and anti-hyperglycemic evaluation of Lantana camara (L.) var. aculeate leaves in alloxan-induced hyperglycemic rats. International Journal of Research in Pharmaceutical Sciences 2010, 1, 247-252.

48. Venkatachalam, T.; Kumar, V.K.; Selvi, P.K.; Maske, A.O.; Anbarasan, V.; Kumar, P.S. Antidiabetic activity of Lantana camara Linn fruits in normal and streptozotocin-induced diabetic rats. J Pharm Res 2011, 4, 1550-2.

49. Ahmad, F.; Rather, M.A.; Siddiqui, M.A. Nematicidal activity of leaf extracts from Lantana camara L. against Meloidogyne incognita (kofoid and white) chitwood and its use to manage roots infection of Solanum melongena L. Brazilian Archives of Biology and Technology 2010, 53, 543-548, https://doi.org/10.1590/S1516-89132010000300006.

50. Qamar, F.; Begum, S.; Raza, S.M.; Wahab, A.; Siddiqui, B.S. Nematicidal natural products from the aerial parts of Lantana camara Linn. Natural product research 2005, 19, 609-613, https://doi.org/10.1080/14786410512331330594.

51. Rajashekar, Y.; Ravindra, K.V.; Bakthavatsalam, N. Leaves of Lantana camara Linn. (Verbenaceae) as a potential insecticide for the management of three species of stored grain insect pests. J Food Sci Technol 2014, 51, 3494-3499, https://doi.org/10.1007/s13197-012-0884-8.

52. Saxena, R.C.; Dixit, O.P.; Harshan, V. Insecticidal action of Lantana camara against Callosobruchus chinensis (Coleoptera: Bruchidae). Journal of Stored Products Research 1992, 28, 279-281, https://doi.org/10.1016/0022-474X(92)90009-F.

53. Shonu, J.; Priyank, I.; Amit, J.; Dubey, B.K. Pharmacognostic and phytochemical evaluation and antipyretic activity of leaves of Lantana camara Linn. Int $J$ of Biomed Adv Res 2011, 2, 270-280, https://doi.org/10.7439/ijbar.v2i8.41.

54. Kumawat, A.; Vyas, N.; Malviya, S.; Kharia, A. Evaluation of anthelmintic potential of ethanolic extract of lantana camara stems. Medicine 2018, 4.

55. Kumar, M.S.; Maneemegalai, S. Evaluation of larvicidal effect of Lantana camara Linn against mosquito species Aedes aegypti and Culex quinquefasciatus. Advances in Biological Research 2008, 2, 39-43.

56. Rajan, D.S.; Varghese, T.A. An evaluation on the larvicidal efficacies of aqueous leaf extracts of Lantana camara and Catharanthus roseus against mosquito larvae. Int J Mosq Res 2017, 4, 93-7.

57. Fatope, M.O.; Salihu, L.; Asante, S.K.; Takeda, Y. Larvicidal activity of extracts and triterpenoids from Lantana camara. Pharmaceutical biology 2002, 40, 564-567, https://doi.org/10.1076/phbi.40.8.564.14654. 